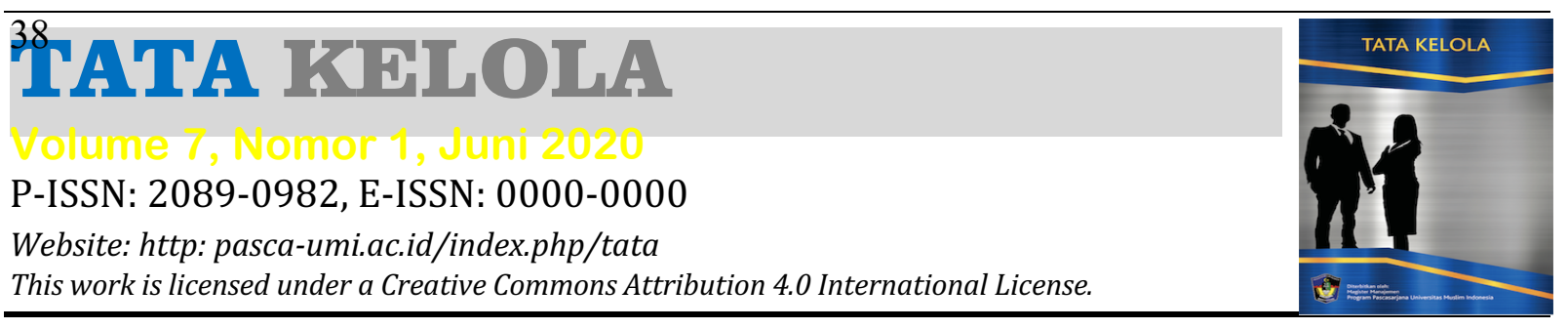

\title{
Pengaruh Rasio Keuangan Terhadap Harga Saham Pada Perusahaan Makanan Dan Minuman Yang Terdaftar Di Bursa Efek Indonesia Pada Tahun 2015-2018
}

\author{
Rahmi Nur Islami ${ }^{1}$, Abdul Rahman Mus ${ }^{2}$, Nurpadillah ${ }^{3}$ \\ 12,3, Magister Manajemen, Universitas Muslim Indonesia. \\ ${ }^{1}$ Koresponden Penulis, E-mail: rahminur.islami@gmail.com
}

\begin{abstract}
ABSTRAK
Penlitian ini dilakukan dengan bertujuan untuk mengetahui dan menganalisis apakah terdapat pengaruh DER terhadap harga saham perusahaan makanan dan minuman yang terdaftar di Bursa Efek Indonesia, pengaruh TATO, pengaruh $C R$ dan pengaruh ROE serta pengaruh yang signifikan DER, TATO, CR dan ROE. Penelitian ini menggunakan data sekunder melalui data laporan keuangan perusahaan makanan dan minuman yang terdaftar di Bursa Efek Indonesia sebanyak 15 dari 27 perusahaan dengan 4 tahun yang memenuhi kriteria sebagai sampel, penelitian dilakukan januari sampai maret 2020. Data dianalisis dengan menggunakan program SPSS. Hasil Penelitian ini menunjukkan bahwa: (1) Debt to Equity Ratio (X1) berpengaruh negatif tapi tidak signifikan terhadap harga saham pada perusahaan makanan dan minuman yang terdaftar di Bursa Efek Indonesia (2) Total Asset turnover (X2) berpengaruh positif tapi tidak signifikan terhadap harga saham pada perusahaan makanan dan minuman yang terdaftar di Bursa Efek Indonesia (3) Current Ratio (X3) berpengaruh negatif dan tidak signifkan terhadap harga saham pada perusahaan saham pada perusahaan makanan dan minuman yang terdaftar di Bursa Efek Indonesia (4) Return on Equity (X4) berpengaruh positif dan signifikan terhadap harga saham pada perusahaan y perusahaan makanan dan minuman yang terdaftar di Bursa Efek Indonesia (5) Debt to Equity Ratio (DER), Total Asset Turnover (TATO), Current Ratio (CR) dan Return on Equity (ROE) berpengaruh positif dan signifikan secara bersama-sama terhadap harga saham pada perusahaan makanan dan minuman yang terdaftar di Bursa Efek Indonesia
\end{abstract}

Kata Kunci: P; Harga Saham; Perusahaan Makanan \& Minuman

\begin{abstract}
This research was conducted by researching to analyze and analyze the DER of the company's stock prices and beverages listed on the Indonesia Stock Exchange, using TATO, CR and the influence of ROE and showed a significant DER, TATO, CR and ROE. This study uses secondary data through the data of financial statements of food and beverage companies listed on the Indonesia Stock Exchange as many as 15 out of 27 companies with 4 years that meet the criteria as a sample, the study was conducted January to March 2020. Data were analyzed using the SPSS program. The results of this study indicate that: (1) Debt to Equity Ratio (X1) has a negative but not significant effect on stock prices on food and beverage companies listed on the Indonesia Stock Exchange (2) Total asset turnover (X2) is positive but not significant on prices shares in food and beverage companies listed on the Indonesia Stock Exchange (3) Current Ratio (X3) shows a negative and insignificant price of shares in food and beverage companies listed on the Indonesia Stock Exchange (4) Equity Returns (4) X4) positive and significant impact on the price of shares of companies and food and beverage companies listed on the Indonesia Stock Exchange (5) Debt to Equity Ratio (DER), Total Asset Turnover (TATO), Current Ratio (CR) and Return on Capital (ROE) have a positive effect and significant jointly with respect to share prices in food and beverage companies listed on the Indonesia Stock Exchange
\end{abstract}

Keyword: Financial Ratios; Stock price; Food \& Beverage Company; 


\section{PENDAHULUAN}

Pasar modal merupakan sumber alternatif selain bank yang memiliki keunggulan penting dibanding bank, salah satu keunggulannya yaitu dengan memanfaatkan dana dari pasar modal, perusahaan tidak perlu menyediakan dana setiap bulan atau setiap tahun untuk membayar bunga. Sebagai gantinya perusahaan harus membayar dividen kepada investor. Pasar modal juga memungkinkan para pemodal untuk memilih berbagai investasi yang sesuai dengan tingkat keuntungan dan tingkat resiko yang diharapkan sehingga memungkinkan terjadinya alokasi dana yang efisien. Namun, tingkat investasi dalam pasar modal masih jauh lebih rendah dibandingkan dengan tingkat investasi dalam tabungan. Salah satu penyebabnya adalah berinvestasi dalam tabungan relatif sederhana, sedangkan berinvestasi dalam saham lebih rumit, karena hasilnya berupa deviden dan perubahan harga saham yang lebih sulit diprediksi (Subekti, 2013).

Harga saham dapat dikatakan sebagai indikator keberhasilan perusahaan dimana kekuatan pasar di bursa ditunjukkan dengan adanya transaksi jual beli saham tersebut dipasar modal. Terjadinya transaksi tersebut didasarkan atas pengamatan para investor terhadap prestasi perusahaan dalam meningkatkan keuntungannya. Perubahan harga saham perusahaan memberikan indikasi terjadinya perubahan prestasi perusahaan selama periode tertentu. Prestasi perusahaan bisa dikaji dari kinerja keuangan perusahaan yang diolah dari laporan keuangan yang dikeluarkan secara periodik.

Darmadji dan Fakhruddin (2016: 167), menyatakan bahwa indeks harga saham adalah suatu indikator yang menunjukkan pergerakan harga saham. Salah satu alat analisis dalam menilai harga saham adalah melalui analisis fundamental perusahaan melalui analisis rasio keuangannya.

Berdasarkan dengan fenomena yang ada investor atau calon investor membeli saham karena tertarik pada keuntungan (return) yang tinggi dan berkelanjutan. Salah satu informasi yang penting untuk diperhatikan oleh para investor dalam melakukan transaksi jual beli saham adalah harga saham itu sendiri. Tingkat keuntungan perusahaan akan mempengaruhi harga saham. Semakin tinggi tingkat keuntungan perusahaan, maka semakin tinggi harga saham, sebaliknya semakin rendah tingkat keuntungan, maka semakin rendah harga saham perusahaan tersebut.

Banyak komponen rasio keuangan yang ada di laporan keuangan, namun tidak semua komponen tersebut memberikan pengaruh terhadap harga saham. Sebab tidak semua rasio dibutuhkan oleh investor, beberapa rasio keuangan mungkin sangat penting bagi manajemen tetapi kurang penting bagi investor. Hal ini ditunjukkan oleh penelitian terdahulu yang berhubungan dengan pengaruh rasio keuangan terhadap harga saham yaitu penelitian Murwanti (2016) tentang pengaruh return on assets (ROA), return on equity (ROE), net profit margin (NPM), earning per share (EPS), dan price earning ratio (PER) terhadap harga saham pada perusahaan perbankan. Hasil penelitian menunjukkan NPM dan EPS berpengaruh terhadap harga saham, sedangkan ROA, ROE, dan PER tidak berpengaruh terhadap harga saham. Secara simultan variable ROA, ROE, NPM, EPS, dan PER berpengaruh terhadap harga saham. Penelitian lain yaitu oleh Suharno (2016) tentang pengaruh 
CR, DER, ROA, TATO dan PER terhadap harga saham pada perusahaan farmasi. Hasil penelitian menunjukkan secara parsial variabel ROA, TATO dan PER berpengaruh signifikan terhadap harga saham, sedangkan CR dan DER tidak berpengaruh signifikan. Secara simultan variabel CR, DER, ROA, TATO dan PER berpengaruh terhadap harga saham.

\section{TINJAUAN PUSTAKA}

1. Pengertian Harga Saham

Menurut Anoraga (2006: 229), harga saham adalah nilai sekarang dari arus kas yang akan diterima oleh pemiliksaham dikemudian hari. Sedangkan menurut Sutrisno (2009: 16), harga saham adalah nilai saham yang terjadi akibat diperjual-belikan saham tersebut di pasar sekunder.

2. Rasio Perputaran Total Aktiva

Rasio Perputaran Total Aktiva (Total Assets Turn Over) merupakan rasio yang digunakan untuk mengukur perputaran semua aktiva yang dimiliki perusahaan. Kemudian juga mengukur berapa jumlah penjualan yang diperoleh dari tiap rupiah aktiva.

3. Debt to Equity Ratio

Debt to Equity Ratio merupakan rasio yang digunakan untuk menilai utang dengan ekuitas. Untuk mencari rasio ini dengan cara membandingkan antara seluruh utang, termasuk utang lancer dengan seluruh ekuitas.

4. Rasio Lancar

Rasio lancar atau current ratio, merupakan rasio untuk mengukur kemampuan perusahaan membayar kewajiban jangka pendek atau utang yang segera jatuh tempo pada saat ditagih secara keseluruhan.

5. Return on Equity (ROE)

Hasil pengembalian ekuitas atau Return on Equity atau rentabilitas modal sendiri, merupakan rasio untuk mengukur laba bersih sesudah pajak dengan modal sendiri. Rasio ini menunjukkan efisiensi penggunaan modal sendiri. 
Gambar 1.

Kerangka konseptual

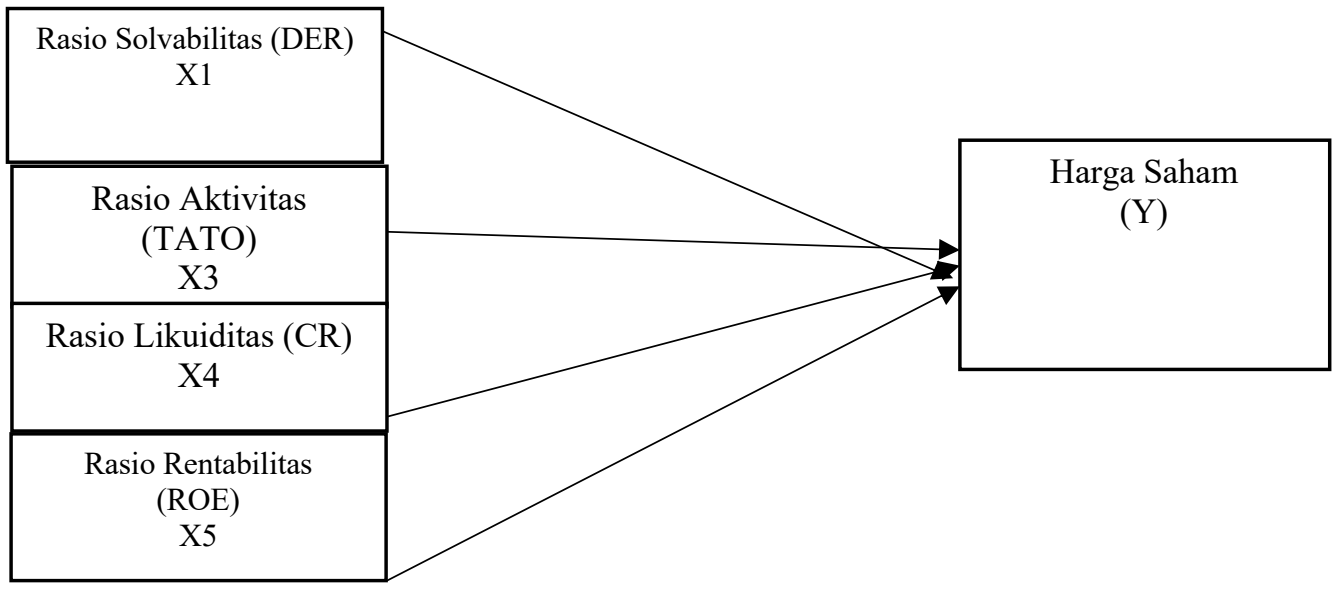

\section{METODE PENELITIAN}

Analisis data dilakukan dengan menggunakan regresi linier berganda yaitu bertujuan untuk menguji dan menganalisis, baik secara parsial maupun secara simultan pengaruh Debt to equity ratio, Earning per share, Total asset turn over, Current ratio dan Return on equity ratio terhadap Harga Saham Perusahaan makanan dan minuman yang terdaftar di Bursa Efek Indonesia (BEI) yang diolah dengan program Statistical Package For Social Science (SPSS).

\section{Statistik Deskriptif}

Statistik deskriptif digunakan untuk mendeskripsikan variabel-variabel dalam penelitian ini. Alat analisis yang digunakan adalah rata-rata, standar deviasi, maksimum, dan minimum. (Ghozali, 2011). Statistik deskriptik menyajikan ukuranukuran numerik yang sangat penting bagi data sampel. Uji statistik deskriptif tersebut dilakukan dengan program SPSS.

\section{Uji Asumsi Klasik}

Uji asumsi klasik adalah persyaratan statistik yang harus dipenuhi pada analisis regresi linear berganda (Ghozali, 2009). Tujuan dari dilakukannya uji asumsi klasik ini adalah untuk memastikan bahwa model yang digunakan dalam penelitian merupakan model yang layak dan dapat memberikan hasil pengujian hipotesis yang akurat. Uji asumsi klasik yang dilakukan dalam penelitian ini meliputi uji normalitas dan uji multikolinearitas.

\section{a Uji Normalitas}

Uji normalitas bertujuan untuk menguji apakah dalam model regresi, variabel pengganggu atau residual memiliki distribusi normal (Ghozali, 2006). Uji normalitas dilakukan untuk mengetahui apakah data yang diambil berasal dari populasi yang berdistribusi normal atau tidak. 


\section{b. Uji Multikolinieritas}

Uji multikolinearitas diimplementasikan untuk mengobservasi kolerasi antar variable bebas. Adanya multikolinieritas dalam model persamaan regresi yang digunakan akan menghasilkan estimasi yang bias.

c. Uji Heteroskedastisitas

Uji heterokedastisitas bertujuan menguji apakah dalam model regresi terjadi ketidaksamaan variance dari residual satu pengamatan ke pengamatan lain.

\section{d. Uji Autokorelasi}

Uji autokorelasi adalah untuk melihat apakah terjadi korelasi antara suatu periode $t$ dengan periode sebelumnya $(t-1)$.

\section{HASIL PENELITIAN DAN PEMBAHASAN}

\section{Uji Hipotesis}

\section{a. Persamaan Regresi Linear Berganda}

Pengujian hipotesis yang digunakan dalam penelitian ini adalah regresi linear berganda. Analisis regresi linear berganda ini bertujuan untuk menguji sejauh mana dan bagaimana arah variabel-variabel independen berpengaruh terhadap variabel dependen. Model persamaan regresi tersebut sebagai berikut:

$$
\mathrm{Y}=\mathrm{a}+\mathrm{b}_{1} \mathrm{X}_{1}+\mathrm{b}_{2} \mathrm{X}_{2}+\mathrm{b}_{3} \mathrm{X}_{3}+\mathrm{b}_{4} \mathrm{X}_{4}+\mathrm{e}
$$

Keterangan :

\section{b. Uji $t$ (parsial)}

$\begin{array}{lll}\mathrm{Y}= & \text { Harga saham } \\ \mathrm{X}_{1} & = & \text { DER } \\ \mathrm{X}_{2} & = & \text { EPS } \\ \mathrm{X}_{3} & = & \text { TATO } \\ \mathrm{X}_{4} & = & \text { CR } \\ \mathrm{a} & = & \text { konstanta regresi } \\ \mathrm{b}_{1}, \mathrm{~b}_{2}, \mathrm{~b}_{3}, \mathrm{~b}_{4}, & = & \text { koefisien regresi } \\ \mathrm{e} & = & \text { error }\end{array}$

Uji parsial digunakan untuk mengetahui apakah variabel independen $(X)$ secara individu berpengaruh signifikan terhadap variabel dependen (Y).

\section{Uji Hipotesis}

\section{a. Analisis Pengaruh Secara Parsial (Uji t)}

Uji $t$ ini merupakan pengujian variabel independen secara parsial terhadap variabel dependen. Dalam penelitian ini uji t digunakan untuk mengetahui pengaruh Return on Equity (ROE), Debt to Equity Ratio (DER), Current Ratio (CR), Earning Per Share (EPS), Price Earning Ratio (PER) dan Ukuran Perusahaan (UP) terhadap haga saham pada perusahaan yang terdaftar di Jakarta Islamic Index (JII) periode tahun 20152017. Adapun berdasarkan perhitungan diperoleh hasil sebagai berikut: 


\begin{tabular}{|c|c|c|c|c|c|c|}
\hline \multirow{2}{*}{\multicolumn{2}{|c|}{ Model }} & \multicolumn{2}{|c|}{ Unstandardized Coefficients } & \multirow{2}{*}{$\begin{array}{l}\text { Standardized } \\
\text { Coefficients } \\
\text { Beta }\end{array}$} & \multirow[b]{2}{*}{$\mathrm{t}$} & \multirow[b]{2}{*}{ Sig. } \\
\hline & & B & Std. Error & & & \\
\hline 1 & (Constant) & -6.199 & 26.084 & & -.238 & .813 \\
\hline & DER & -.254 & .166 & -.165 & -1.529 & .134 \\
\hline & TATO & 1.397 & 3.258 & .045 & .429 & .670 \\
\hline & $\mathrm{CR}$ & -.236 & .246 & -.123 & -.958 & .344 \\
\hline & $\mathrm{ROE}$ & .557 & .094 & .746 & 5.919 & .000 \\
\hline
\end{tabular}

Sumber: Data diolah Spss 25

$$
\begin{aligned}
\mathrm{T} \text { tabel } & =\quad / 2 ; ; \mathrm{n}-\mathrm{k}-1 \\
& =0,05 / 2 ; 45-4-1 \\
& =2,021
\end{aligned}
$$

Berdasarkan Tabel 11, maka dapat diketahui pengaruh masing- masing variabel sebagai berikut:

a. Pengaruh Debt to equity ratio (X1) terhadap Harga Saham (Y)

Dari tabel 4.7 diperoleh nilai t hitung sebesar -1529 yang artinya thitung sebesar $-1,529<$ ttabel sebesar 2,021 dan untuk taraf signifikannya 0,134<0,05 maka dapat disimpulkan bahwa Ho diterima dan Ha ditolak artinya variabel Debt to equity ratio berpengaruh tidak signifikan terhadap harga saham pada perusahaan makanan dan minuman yang terdaftar di Bursa Efek Indonesia periode tahun 2016-2018.

Pengaruh Total Asset Turnover (X2) terhadap Harga Saham (Y)

Dari tabel 4.7 diperoleh nilai t hitung sebesar 0,429 yang artinya $t$ hitung sebesar $0,429<\mathrm{t}$ tabel sebesar 2,021 dan untuk taraf signifikannya 0,670<0,05 maka dapat disimpulkan bahwa Ho diterima dan Ha ditolak artinya variabel Total Asset Turnover tidak berpengaruh signifikan terhadap harga saham pada perusahaan makanan dan minuman yang terdaftar di Bursa Efek Indonesia periode tahun 2016-2018.

b. Pengaruh Current ratio (X3) terhadap Harga Saham (Y)

Dari tabel 4.7 diperoleh nilai $t$ hitung sebesar - 0,958 yang artinya $t$ hitung sebesar $-0,958<t$ tabel sebesar 2,021 dan untuk taraf signifikannya 0,334 $<0,05$ maka dapat disimpulkan bahwa Ho diterima dan Ha ditolak artinya variabel Current ratio tidak berpengaruh signifikan terhadap harga saham pada perusahaan makanan dan minuman yang terdaftar di Bursa Efek Indonesia periode tahun 2016-2018.

c. Pengaruh Return On Equity (X4) terhadap Harga Saham (Y)

Dari tabel 4.7 diperoleh nilai thitung sebesar 5,919 yang artinya $t$ hitung sebesar $5,919>\mathrm{t}$ tabel sebesar 2,021 dan untuk taraf signifikannya 0,000 $<0,05$ maka dapat disimpulkan bahwa Ho ditolak dan Ha diterima artinya variabel Return OnEquity berpengaruh signifikan terhadap harga saham pada perusahaan makanan dan minuman yang terdaftar di Bursa Efek Indonesia periode tahun 2016-2018.

d. Analisis Pengaruh Secara Simultan (Uji F)

Uji F digunakan untuk mengetahui pengaruh semuavariabel independen yang terdapat di dalam model secara bersama-sama (simultan) terhadap variabel dependen. Hasil pengujian F statistik diperoleh hasil sebagai berikut: 


\begin{tabular}{|c|c|c|c|c|c|c|}
\hline \multirow[b]{2}{*}{ Model } & & \multicolumn{5}{|c|}{$\begin{array}{l}\text { Tabel 12. Uji F } \\
\text { ANOVA }^{a}\end{array}$} \\
\hline & & Sum of Squares & $\mathrm{df}$ & Mean Square & $\mathrm{F}$ & Sig. \\
\hline 1 & Regression & 24.920 & 4 & 6.230 & 18.157 & $.000^{\mathrm{b}}$ \\
\hline & Residual & 13.725 & 40 & .343 & & \\
\hline & Total & 38.646 & 44 & & & \\
\hline
\end{tabular}

Sumber : Data diolah Spss 25

$$
\begin{aligned}
\mathrm{F} \text { tabel } & =\quad ; \mathrm{k}-1 ; \mathrm{n}-\mathrm{k} \\
& =0,05 ; 5-1 ; 48-6 \\
& =0,05 ; 4 ; 40 \\
& =2,60
\end{aligned}
$$

Berdasarkan hasil perhitungan diperoleh Fhitung $=89,064>2,60$ (Sig. $=0,000<0,05$ ) sehingga H0 ditolak, Debt to Equity Ratio (DER), total asset turnover (TATO), Current Ratio (CR), Return on Equity (ROE), artinya secara bersama-sama berpengaruh terhadap harga saham pada perusahaan makanan dan minuman yang terdaftar di Bursa Efek Indonesia periode tahun 2016-2018 sehingga pemilihan Debt to Equity Ratio (DER), total asset turnover (TATO), Current Ratio (CR), Return on Equity (ROE), sebagai prediktor dari harga saham pada perusahaan makanan makanan dan minuman yang terdaftar di Bursa Efek Indonesia periode tahun 2016-2018 sudah tepat.

Keofisien determinasi yaitu untuk mengukur proporsi atau presentasi sumbangan dari seluruh variabel bebas $(X)$ yang terdapat dalam model regresi terhadap variabel terikat $(\mathrm{Y})$. Dalam hal ini untuk mengukur proporsi atau presentasi sumbangan dari Debt to Equity Ratio (DER), total asset turnover (TATO), Current Ratio (CR), dan Return on Equity (ROE), terhadap harga saham pada perusahaan makanan makanan dan minuman yang terdaftar di Bursa Efek Indonesia periode tahun 2016-2018. Hasil pengujian koefisien determinasi (R2) diperoleh hasil sebagai berikut:

Tabel 2. Koefisen Determinasi

Model Summaryb

\begin{tabular}{lr|r|r|rr|r} 
Model & R & R Square & $\begin{array}{c}\text { Adjusted R } \\
\text { Square }\end{array}$ & $\begin{array}{c}\text { Std. Error of the } \\
\text { Estimate }\end{array}$ & Durbin-Watson \\
\hline 1 & $.803 \mathrm{a}$ & .645 & .609 & .58577 & 2.109 \\
\hline
\end{tabular}

Sumber: Data diolah Spss 25

Berdasarkan hasil perhitungan Uji koefisien determinan seperti pada tabel 13 diatas dapat diketahui bahwa pengaruh dari keempat variabel independen terhadap variabel dependen dinyatakan dengan nilai koefisien determinan sebesar 64,5 atau $64,5 \%$. Hal ini menunjukan bahwa $64,5 \%$ variasi dari harga saham yang bisa dijelaskan oleh variasi dari keempat variabel independen Debt to Equity Ratio (DER), total asset turnover (TATO), Current Ratio (CR), dan Return on Equity (ROE), Sedangkan sisanya sebesar $100 \%-64,5 \%=35,5 \%$ dijelaskan oleh variabel- variabel lain di luar penelitian ini. 


\section{KESIMPULAN}

Berdasarkan hasil analisis data dan pembahasan data yang telah diuraikan pada babbab sebelumnya tentang pengaruh Debt to Equity Ratio (DER), Total Asset Turnover (TATO), Current Ratio (CR) dan Return on Equity (ROE), terhadap harga saham pada perusahaan makanan dan minuman yang terdaftar di Bursa Efek Indonesia,maka penulis dapat menarik kesimpulan sebagai berikut :

1. Debt to Equity Ratio (X1) berpengaruh negatif tapi tidak signifikan terhadap harga saham pada perusahaan makanan dan minuman yang terdaftar di Bursa Efek Indonesia 2016-2018 yang artinya ketika nilai DER menglami kenaikan ataupun tidak maka tidak akan berpengaruh terhadap harga saham.

2. Total Asset turnover (X2) berpengaruh positif tapi tidak signifikan terhadap harga saham pada perusahaan makanan dan minuman yang terdaftar di Bursa Efek Indonesia 2016-2018 yang artinya ketika nilai TATO mengalami kenaikan ataupun tidak akan mempengaruhi harga saham tapi tidak signifikan.

3. Current Ratio (X3) berpengaruh negatif dan tidak signifkan terhadap harga saham pada perusahaan saham pada perusahaan makanan dan minuman yang terdaftar di Bursa Efek Indonesia 2016-2018 ini berarti ketika nilai CR mengalami fluktuasi maupun tidak, maka tidak akan mempengaruhi pertumbuhan harga saham di suatu perusahaan.

4. Return on Equity (X4) berpengaruh positif dan signifikan terhadap harga saham pada perusahaan y perusahaan makanan dan minuman yang terdaftar di Bursa Efek Indonesia 2016-2018, berarti bahwa ketika nilai ROE tinggi harga saham akan mengalami perubahan dan ketika ROE rendah maka harga saham juga akan berubah.

5. Debt to Equity Ratio (DER), Total Asset Turnover (TATO), Current Ratio (CR) dan Return on Equity (ROE) berpengaruh positif dan signifikan secara bersama-sama terhadap harga saham pada perusahaan makanan dan minuman yang terdaftar di Bursa Efek Indonesia 2016-2018.

\section{DAFTAR PUSTAKA}

Anoraga, P. (2006). Pengantar Pasar Modal. Jakarta: Rineka Cipta.

Arikunto, S. (2010). Prosedur Penelitian Suatu Pendekatan Praktik. Rhineka Cipta. Jakarta.

Badan Penelitian dan Pengembangan Pertanian, Departemen Pertanian. (2015). Statistik Penelitian Pertanian 2015.20 (Online) (http://www.litbang.pertanian.go.id/spp/spp-2015, diakses pada 4 Mei 2018).

Badan Pusat Statistik. (2015). Penduduk 15 Tahun Ke Atas yang Bekerja menurut Lapangan Pekerjaan Utama 2015.2 (Online), (https://www.bps.go.id/linkTabelStatis/view/id/970, diakses pada 11 Februari 2016).

Basuki, A. T. \& Yuliadi, I. (2015). Ekonometrika: Teori \& Aplikasi. Yogyakarta: Mitra Pustaka Nurani. 
Brigham, E. F. \& Houston, J. F. (2010). Manajemen Keuangan. Jakarta: Erlangga. Bursa Efek Indonesia. (2010). Saham. (Online), (www.idx.co.id, diakses pada 15 Maret 2017)

Darmadji, T dan Fakhruddin, M. H. (2006). Pasar Modal di Indonesia. Jakarta: Salemba Empat.

Fahmi, I. (2015). Manajemen Keuangan Perusahaan dan Pasar Modal. Jakarta: Penerbit Mitra Wacana Media.

Glienmourinsie, D. (2017). Pasar Modal Beri Kontribusi 12\% ke Ekonomi RI. (Online). (https:/ / ekbis.sindonews.com/read/1187148/32/pasar-modal-berikontribusi-12-ke-ekonomi-ri-1489137620, diakses pada 5 Mei 2018).

Gujarati, N. D. \& Porter, D. O. (2012). Dasar-dasar Ekonometrika. Jakarta: Salemba Empat.

Harahap, S. S. (2013). Analisis Kritis atas Laporan Keuangan. Jakarta: Rajawali Pers. 